\title{
Observations of cattle use of prairie dog towns
}

\author{
DEBRA A. GUENTHER AND JAMES K. DETLING
}

Authors are Research Associate, Natural Resource Ecology Laboratory (NREL) and Professor, Department of Biology and senior Research Scientist, NREL, Colorado State University, Fort Collins, Colo. 80523. At the time of the research, the senior author was Research Assistant, Department of Biology, Colorado State University, Fort Collins, Colo.

\begin{abstract}
We investigated the use of prairie dog towns by cattle (Bos taurus) on the shortgrass steppe of northeastern Colorado by conducting surveys of cattle and vegetation from June to August 1999. Cattle presence and behavior were recorded 3 times a week during driving surveys of 15 black-tailed prairie dog (Cynomys ludovicianus) towns. A subset of 3 pastures with prairie dog towns was intensively surveyed twice weekly wherein the habitat and activity of a randomly chosen focal animal was recorded every 6 minutes for 3.5 hours. Bite and step counts of other individuals were recorded for 5-minute intervals. Vegetation height and cover data were collected monthly on each of 6 habitats. Results from driving surveys and intensively surveyed pastures were similar; cattle neither significantly preferred nor avoided prairie dog towns. Bare ground cover on prairie dog towns did not significantly differ from most other habitats, but vegetation on prairie dog towns was significantly shorter on $($ mean $=6.7$ $\mathrm{cm})$ than that off $($ mean $=11.9 \mathrm{~cm})$ prairie dog towns. Nevertheless, foraging observations indicated that there was no significant difference between cattle foraging rates on swales (70.9 bites/min) and prairie dog towns (69.5 bites/min). Thus, cattle on the shortgrass steppe appear to use prairie dog towns in proportion to their availability and, while there, they graze as intensively as they do on habitats not inhabited by prairie dogs.
\end{abstract}

Key Words: cattle, prairie dogs, Cynomys ludovicianus, grazing, shortgrass steppe

Black-tailed prairie dogs (Cynomys ludovicianus) greatly alter vegetation (Coppock et al. 1983a, Fahnestock and Detling 2002) and share many preferred forage species with cattle (Bos taurus) (Hansen and Gold 1977), leading to speculation about competition between these species for forage. On the shortgrass steppe, prairie dog activities increase the number of both forb and grass species and, through selective grazing, exert selective pressure against blue grama (Bouteloua gracilis [H.B.K.] Lag. ex Griffiths) and in favor of buffalograss (Buchloe dactyloides [Nutt.] Engelm.) (Bonham and Lerwick 1976). In mixed-grass prairie, canopy height decreases as prairie dogs clip vegetation

Funding for this study was provided by the National Science Foundation Long Term Ecological Research (LTER) program (NSF Grant Number DEB-9632852). We are grateful to Dr. Larry Rittenhouse and Dr. David Steingraeber for their assistance in developing this study. Dr. Tom Hobbs contributed his time and analytical advice. The Shortgrass Steppe LTER and USDA-ARS Central Plains Experimental Range staff provided invaluable knowledge and logistical support. We also thank Bob Peterson and Mark Ball of the Pawnee National Grasslands for access to information.

Manuscript accepted 24 Oct. 02.

\section{Resumen}

Investigamos el uso de las colonias de los perritos de la pradera por el ganado (Bos taurus) en la estepas de zacates cortos del nordeste de Colorado, mediante la conducción de muestreos del ganado y la vegetación de Junio a Agosto de 1999. La presencia de ganado y su comportamiento se registro 3 veces por semana durante el periodo de muestreo en el recorrido en vehículo de 15 colonias de perritos de la pradera de cola negra (Cynomys ludovicianus). Un subgrupo de 3 potreros con colonias de perritos de la pradera se muestreo intensivamente, 2 veces por semana, y cada 6 minutos durante 3.5 horas se registro el hábitat y las actividades de animales elegidos aleatoriamente. Los conteos de mordidas y los pasos de otros animales se registraron en intervalos de 5 minutos. Mensualmente se colectaron datos de cobertura y altura de la vegetación en cada uno de los 6 hábitats. Los resultados de los muestreos en vehículo y los de los potreros intensivamente muestreados fueron similares, el ganado ni prefirió ni evitó significativamente las colonias de los perritos de la pradera. El porcentaje de suelo desnudo en las colonias de los perritos de la pradera no difirió significativamente en la mayoría de los otros hábitats, pero la vegetación en las colonias de los perritos de la pradera fue significativamente mas corta dentro $($ media $=6.7 \mathrm{~cm}$ ) de la colonia que fuera de ella (media $11.9 \mathrm{~cm}$ ). Sin embargo, las observaciones de forrajeo indicaron que no hubo diferencia significativa entre las tasas de forrajeo del ganado fuera (70.9 mordidas/minuto) y dentro de las colonias de los perritos de la pradera (69.5 mordidas/min). Así, el ganado en las estepas de zacates cortos parece usar las colonias de los perritos de la pradera en proporción a su disponibilidad y ellos apacientan tan intensivamente en las colonias de perritos de la pradera como en los hábitats no colonizados por esta especie.

(Archer et al. 1987, Day and Detling 1994); as taller grass species decline shorter species become relatively more abundant (Painter et al. 1993). As the colony ages, older areas become dominated by forbs and dwarf shrubs, while more recently occupied areas remain grass-dominated (Coppock et al. 1983a, Whicker and Detling 1988, Fahnestock and Detling 2002).

On both the shortgrass steppe and mixed-grass prairie there is diet overlap between cattle and prairie dogs. On the Colorado shortgrass steppe, Hansen and Gold (1977) reported a 64\% annual similarity in diet. In western Oklahoma, O'Meilia et al. (1982) observed lower biomass of grass species palatable to cattle on prairie dog towns than on control pastures, and speculated that there was a high degree of competition between cattle and prairie dogs.

Despite this speculation, some studies have shown that prairie dog grazing may actually positively affect large herbivores by 
influencing forage quality. On the mixedgrass prairie of South Dakota, Coppock et al. (1983a) found greater crude protein concentrations, in vitro digestibilities, and live:dead ratios in plants from prairie dog towns than in plants of the same species from uncolonized areas. Even though prairie dog towns had $40 \%$ less forage standing crop than surrounding uncolonized areas, bison (Bison bison) strongly selected prairie dog colonies to graze on whenever they were in the vicinity of one (Coppock et al., 1983b). In another study, Krueger (1986) concluded that rather than a competitive relationship, bison and prairie dogs have a mutually beneficial relationship. Vanderhye (1985) quantified diet quality differences on and off prairie dog towns and used Swift's (1983) ruminant nutrition model to simulate effects on bison from feeding on prairie dog towns. Her results indicated that bison that selectively feed on prairie dog towns in the summer would significantly increase body weight relative to those feeding exclusively off prairie dog towns.

Cattle have replaced bison as the dominant herbivore on most of the Great Plains. While some studies have examined the effects of prairie dog grazing on forage preferred by cattle or diet overlap between the 2 herbivores (Hansen and Gold 1977, O'Meilia et al. 1982, Uresk 1983, 1984, 1985), little information is available regarding whether cattle actually preferentially graze on prairie dog towns.

The objectives of this study were to: (a) obtain estimates of cattle use on vs. off of prairie dog towns across the Shortgrass Steppe Long Term Ecological Research Site (SGS-LTER) through driving surveys; (b) to intensively study a subset of the pastures from the driving surveys to quantify the amount of time cattle spend on prairie dog towns compared to each of several other habitats; (c) compare foraging rates of cattle on prairie dog towns with those on other habitats in the intensive survey pastures; and (d) measure vegetation cover by species and height on and off prairie dog towns in the intensive survey pastures to determine whether vegetation differences correlated with cattle grazing activities.

Methods
Study Area
This research was conducted at the
SGS-LTER in northeastern Colorado (Lat.
$40^{\circ} 49^{\prime}$ N, Long $104^{\circ} 46^{\prime} \mathrm{W}$ ) and includes
the Pawnee National Grassland (PNG) and

the USDA-ARS Central Plains Experimental Range (CPER). The dominant plant species are blue grama and prickly pear cactus (Opuntia polyacantha Haw.), with blue grama making up $90 \%$ of the basal plant cover. Annual precipitation ranges from $300-550 \mathrm{~mm}$, and $70 \%$ occurs between May and September as localized thunderstorms (Lauenroth and Milchunas, 1991). Most soils are well drained loams or sandy loams, and the topography consists of rolling hills at an elevation of $1,310 \mathrm{~m}$ to 1,935m (Hazlett 1998).

Cattle are present on the pastures used for this study from mid-May until midOctober. Pasture sizes for this study range from 130 to 2,378 ha, and the black-tailed prairie dog towns range in size from 1.7 to 81.6 ha and occupy 0.3 to $10.7 \%$ of the those pastures (Table 1).

Most pastures contain stock tanks to supply cattle with water. For this study, we chose prairie dog towns that were not adjacent to or surrounding water tanks. Pastures are grazed at "moderate" stocking rates $(1.74 \mathrm{ha} / \mathrm{cow} / \mathrm{month}$, Bob Peterson, pers. comm.). Most of these prairie dog towns are less than 10 years old because of plague-induced die outs and subsequent prairie dog recolonizations (Mark Ball, pers. comm.).

\section{Driving Surveys}

We conducted driving surveys to obtain SGS-LTER-wide estimates of cattle use of prairie dog towns approximately 3 times per week from 28 May to 15 Aug. 1999, for a total of 31 surveys of each of 15 prairie dog towns in 12 pastures (Table 1). Because cattle are most active the half hour before sunrise until approximately 3 hours after sunrise, and from 3 hours before sunset to a half hour after sunset (Arnold and Dudzinski 1978), we restricted our surveys to those times. Time (morning vs. evening), starting location,

Table 1. Characteristics of pastures and prairie dog towns surveyed during summer 1999, on the Shortgrass Steppe LTER. All allotments on the Pawnee National Grasslands had cow/calf herds. On the Central Plains Experimental Range pastures 5W, 22W, and 28N had steer herds, pasture 29-30 had yearling breeders, and pasture 27-34 had stock heifers. Age of towns were determined from U.S. Forest Service records and indicate the number of consecutive years towns have been active up until the time of this study.

\begin{tabular}{lcccccc}
\hline \hline & $\begin{array}{c}\text { pasture } \\
\text { size }\end{array}$ & $\begin{array}{c}\text { U.S. Forest } \\
\text { Service } \\
\text { town } \#\end{array}$ & $\begin{array}{c}\text { area } \\
\text { of town }\end{array}$ & $\begin{array}{c}\text { pasture } \\
\text { occupied } \\
\text { by town }\end{array}$ & $\begin{array}{c}\text { age of } \\
\text { cattle }\end{array}$ \\
\hline Pawnee National Grasslands & (ha) & & $($ ha) & $(\%)$ & (No.) & (Yrs.) \\
Roe & 1468 & 79 & 5.6 & 0.4 & 175 & 6 \\
Coal & 1535 & 51 & 8.7 & 0.6 & 144 & 6 \\
Keota & 2378 & 17 & 14.3 & 0.6 & 168 & 2 \\
Simmons & 1948 & 13 & 5.1 & 0.3 & 252 & 18 \\
Fiscus & 534 & 30 & 3.3 & 0.6 & 64 & 5 \\
Box & 1536 & 35 & 40.5 & 2.6 & 144 & 6 \\
Stoneham & 1173 & 5 & 81.6 & 7.0 & & 6 \\
\end{tabular}

Central Plains Experimental Range

\begin{tabular}{lcccccc}
$5 \mathrm{~W}^{1}$ & 130 & $5 \mathrm{~W}$ & 13.9 & 10.7 & 20 & 3 \\
$29-30^{1}$ & 324 & 29 & 7.9 & 2.4 & & 2 \\
& & 30 & 2.4 & 0.7 & 65 & 3 \\
$22 \mathrm{~W}^{1}$ & 130 & 22 & 4.4 & 3.3 & 17 & 2 \\
$27-34$ & 332 & 27 & 3.0 & 0.9 & & 3 \\
$28 \mathrm{~N}$ & & $28 \mathrm{NE}$ & 1.7 & 0.5 & 62 & 3 \\
\hline
\end{tabular}

${ }^{1}$ Pastures also used for intensive surveys. 
and order of visitation of the towns were changed with each survey. Prairie dog towns were either entirely visible from the road with 7 x 35 binoculars or could be seen by walking to a nearby vantage point. Pastures were only chosen for the survey if all of the prairie dog towns on the pasture could be viewed at the time of the survey. These prairie dog towns encompassed a variety of soil types and upland and lowland sites. The number of cattle on each prairie dog town and their behaviors (grazing, resting, traveling, or standing still) were recorded. Cattle were considered to be grazing if feeding while moving or standing still. Resting was defined as cattle lying down, and traveling was movement with the head up. For this general overview, we were only concerned with whether the cattle were on or off the towns. Pastures were often very large, and not all of the cattle could be seen at the time of the survey if they were off of the prairie dog town. Consequently, behavior of cattle off prairie dog towns was not recorded for the driving surveys.

Driving survey data were analyzed using resource selection functions (Manly et al. 1993). The ratio of the proportion of the cattle population occupying a habitat $\left(\mathrm{o}_{\mathrm{i}}\right)$ to the proportion of pasture area the habitat occupies $\left(\pi_{\mathrm{i}}\right)$ gives a selection ratio $\left(\mathrm{w}_{\mathrm{i}}\right)$, where $\mathrm{i}=$ habitat (in this case, on or off prairie dog towns):

$$
\mathrm{w}_{\mathrm{i}}=\mathrm{o}_{\mathrm{i}} / \pi_{\mathrm{i}}
$$

These selection ratios are standardized $\left(B_{i}\right)$ to values between 0 and 1 wherein:

$$
\mathrm{B}_{\mathrm{i}}=\mathrm{w}_{\mathrm{i}} /\left(\sum_{\mathrm{i}=2}^{1} \mathrm{w}_{\mathrm{i}}\right)
$$

Standardized selection ratios can be interpreted as probabilities, such as the probability of selecting habitat $i$ next if all the habitats were equally available. When only 2 habitats are considered (e.g. on and off towns), values above 0.5 indicate preference for a habitat, values of 0.5 indicate random use, and values below 0.5 indicate avoidance of a habitat. Chi-square values were calculated for the selection ratios to determine significant differences from random use (0.5).

\section{Intensive Surveys}

To obtain a more detailed assessment of where cattle were spending their time, a subset of 3 smaller pastures from the driving surveys, located on the CPER, were chosen for more intensive surveys conducted from 4 June to 20 Aug. 1999 (Tables 1 and 2). In each of these intensive study areas, the entire pasture could be observed from several vantage points so the entire pasture was considered the home range of the cattle and all habitat types could be observed. Plant communities on these pastures were divided into 6 habitats: prairie dog towns, swales, rocky ridgetops, uplands, planted crested wheatgrass (Agropyron cristatum [L.] Gaertn.) strips, and Atriplex canescens (Pursh) Nutt. dominated terraces (Table 2).

Table 2. Habitats of the 3 intensive survey pastures on the Central Plains Experimental Range and relative composition of the habitats within each pasture.

\begin{tabular}{lrrr}
\hline \hline & \multicolumn{3}{c}{ Pasture } \\
Habitat & 22W & \multicolumn{1}{c}{$5 \mathrm{~W}$} & \multicolumn{1}{c}{$29-30$} \\
\hline & $-------(\%)$ & ----- \\
upland & 86.0 & 0.0 & 75.4 \\
Atriplex terrace & 0.0 & 73.7 & 16.1 \\
prairie dog town & 3.3 & 10.7 & 3.2 \\
swale & 7.9 & 6.3 & 3.0 \\
rocky ridgetop & 2.8 & 4.4 & 2.1 \\
crested wheatgrass & 0.0 & 4.9 & 0.0 \\
\hline
\end{tabular}

During a 3.5 hour feeding bout (morning or evening), a randomly chosen focal animal (Altmann 1974) was observed every 6 minutes. To minimize disturbance, cattle were observed from a vehicle at a distance of at least $1 \mathrm{~km}$, using $7 \times 35$ binoculars or a 15 to $60 \times$ zoom spotting scope. Habitat, instantaneous behavior (grazing, resting, traveling, or other), and number of other cattle within a $50 \mathrm{~m}$ radius were recorded. Frequency of behaviors was analyzed using tests of 2 percentages (Lehner 1996). In between the focal animal observations, we conducted foraging surveys to examine foraging efficiency. The number of bites and steps in a 5-minute period were recorded for randomly chosen individuals. Each jaw movement when the head was touching vegetation constituted a bite and each movement of a front leg was considered a step. Comparison of foraging data between habitats was conducted using an ANOVA and Tukey's HSD procedure.

The 3 pastures were mapped in September with a hand-held Global Positioning System (GPS) unit (Trimble Navigation Ltd., Sunnyvale, Calif. 94086) and areas of each habitat were determined using PC ARC/INFO 3.5.1 and ArcView GIS 3.2 (Environmental Systems Research Institute, Redlands, Calif. 92373). The habitat use data for these 3 pastures were divided into 2 periods (Period $\mathrm{I}=28$ May to $9 \mathrm{July}$, Period II $=12 \mathrm{July}$ to 15 August) and also combined to detect changes in habitat use over the season using log-ratio compositional analysis
(Aebischer et al. 1993). This method examines the proportional habitat use by animals in comparison to habitat availability. Instead of the number of locations, it uses the number of animals as the sample size; therefore, it does not require independence of sequentially collected locations. This method also accounts for the unitsum constraint, a common problem when using compositional data, wherein habitat proportions are non-independent and must sum to 1 . For example, if an animal avoids one habitat, it must spend time in another, leading to an apparent preference for that habitat type. Finally, compositional analysis accounts for the arbitrary definition of habitat preference by allowing habitats to be ranked according to relative use. This technique tests for random use on all habitats. When there is deviance from random use, the available habitats can be ranked from most preferred to least preferred. The data from this study were divided into 2 periods in an attempt to detect any seasonal difference while still having a large enough sample size for meaningful statistical analysis.

Vegetation data were collected in June, July, and August on the 3 intensive survey pastures. Twenty, $0.1 \mathrm{~m}^{2}$ Daubenmire frames (Daubenmire 1959) were placed randomly in each habitat on each pasture to determine plant species composition and canopy cover. Average vegetation height was measured by setting a light cardboard piece over the Daubenmire frame area and measuring the height from the ground to the center of the cardboard. Data from all 3 pastures were combined for vegetation analysis due to the close proximity of the pastures (within $8 \mathrm{~km}$ ) and the similarity in soils and vegetation types. Vegetation heights and canopy cover were analyzed using an ANOVA and Tukey's HSD procedure.

\section{Results}

\section{Driving Surveys}

Standardized resource selection ratios for each pasture across the season for all surveys displayed no clear trend in the use of prairie dog towns by cattle (Fig. 1). A Chi-square test indicated a slight preference $\left(B_{i}=0.527, p=0.003\right)$ for the use of prairie dog towns by cattle for all pastures over the entire sampling period. Of 789 cattle observed on prairie dog towns over the season, $91.4 \%$ were grazing, $5.7 \%$ were resting, $2.9 \%$ were standing still, and none were traveling. 


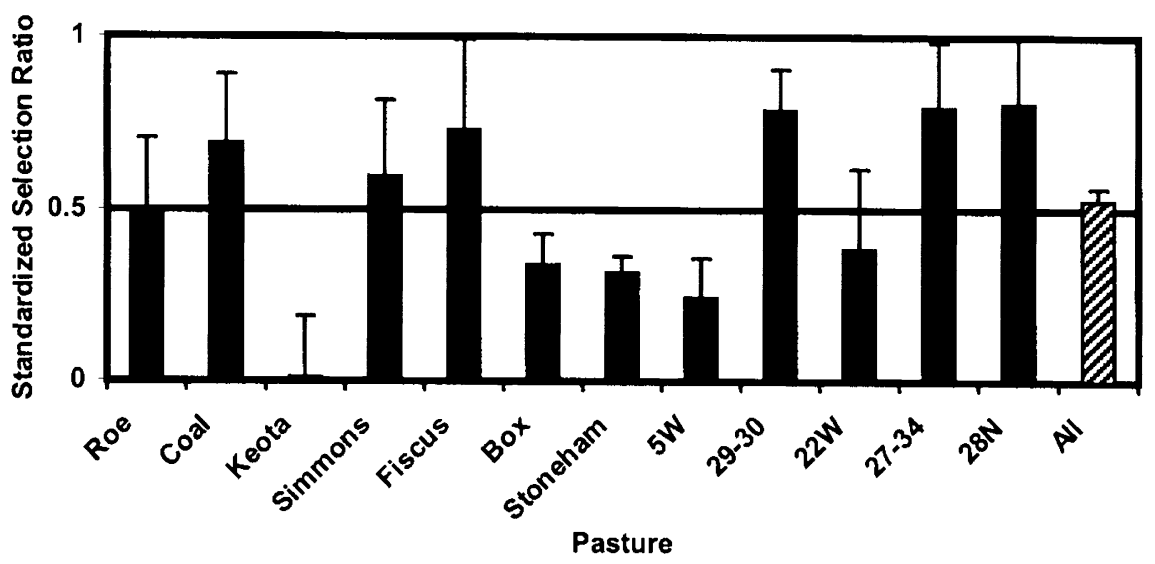

Fig. 1. Standardized resource selection ratios $\left(B_{i}\right)$ and standard error bars for cattle occurring on prairie dog towns from the driving surveys for each pasture and all pastures combined from 28 May to 15 Aug. 1999. Values above 0.5 represent selection for prairie dog towns, values below 0.5 represent avoidance of prairie dog towns, and 0.5 represents random use of prairie dog towns.

\section{Intensive Surveys}

Each of the 3 pastures was surveyed 16 times for a total of 25 surveys for Period I and 23 surveys for Period II. Focal animals were within a $50 \mathrm{~m}$ radius of half or more of the herd $54 \%$ of the time. Cattle did not use habitats randomly on any of the 3 intensively surveyed pastures based on log-ratio compositional analysis (Table 3 ). The 3 pastures used for the intensive surveys were analyzed separately for habitat use due to the differing proportions of each habitat type on the pastures (Table 2). The prairie dog town was consistently ranked last (least preferred habitat) on pasture $22 \mathrm{~W}$, but was not used significantly differently from the rocky ridgetops. On pasture $5 \mathrm{~W}$, cattle used habitats almost in the direct order of availability (Table 2), with the exception of the swale being ranked higher than the prairie dog town. Again, there were no significant seasonal differences, with the town consistently ranked in the middle. Pasture 29-30 revealed the only significant seasonal difference regarding cattle use of prairie dog towns. The town was ranked last in Period I (early summer) and first in Period II (late summer), whereas the swale switched from the first rank in Period I to second to last in Period II. Combined data over the

Behavior observations $(n=1,720)$ of the focal animals (Table 4) indicated that cattle spent the majority of their time grazing during the 3.5 hour observation periods. While on prairie dog towns, cattle spent $60 \%$ of their time grazing, $13 \%$ resting, $15 \%$ traveling, and $12 \%$ doing other activities such as interacting with other cattle or standing still. Focal animals for the logratio compositional analysis spent more overall time in the swales (Table 3 ). However, those same animals spent a higher proportion of their time grazing while on prairie dog towns, uplands, Atriplex terraces, and rocky ridgetops than in the swales (Table 4).

Foraging observations of numbers of bites per step (Fig. 2) revealed few differences between cattle foraging on prairie season for pasture 29-30 ranked the town as second to last. dog towns (mean $=6.3$ bites $/$ step) and most other habitats. Cattle did have significantly fewer bites per step on the rocky ridgetops and upland habitats (4.7, and 4.8 bites/step, respectively) and consequently moved at a faster rate across those habitats. Foraging observations of the number of bites per minute indicated that there was no significant difference between cattle foraging on swales ( 70.9 bites/min) and prairie dog towns ( $69.5 \mathrm{bites} / \mathrm{min})$. The cattle on these 2 habitats had significantly higher foraging rates than on all other habitats.

\section{Vegetation Characterization}

We compared cover for 5 plant species palatable to cattle and 2 non-palatable species, as well as cover of bare ground and litter across all 3 intensively surveyed pastures (Fig. 3). Of the palatable plants, swales had the highest cover of western wheatgrass (Pascopyrum smithii [Rydberg] Love). Prairie dog towns and the Atriplex habitat had the next highest cover of western wheatgrass and they were not significantly different from each other. Prairie dog towns contained significantly less blue grama cover than the Atriplex terraces and upland habitats, but more than swales and crested wheatgrass habitats. The prairie dog towns and swales had significantly more cover of buffalograss than the other habitats. Cover of needleleaf sedge (Carex eleocharis Bailey) and scarlet globemallow (Sphaeralcea coccinea [Pursh] Rydberg var. coccinea) was low $(<5 \%)$ across all habitats.

Of the non-palatable plants (Fig. 3), red three-awn (Aristida purpurea Nuttall var. longiseta [Steud.] Vasey) had low cover $(1.2 \%)$ on the prairie dog towns, and this was lower than on either the rocky ridgetops or upland habitats. Sixweeks fescue (Vulpia octoflora [Walt.] Rydb.) had low $(0-2 \%)$ cover across habitats and few significant differences between habitats. Bare ground cover on prairie dog towns was not significantly different from

Table 3. Results of the log-ratio compositional analysis for the 3 intensive survey pastures including habitat rankings according to use. The designation "cw" refers to the crested wheatgrass habitat, "rocky" refers to rocky ridgetops, and "town" refers to prairie dog town. Period I refers to surveys conducted from 3 June to 8 July 1999, and Period II refers to surveys conducted from 13 July to 21 Aug. 1999. Within a row, and within a pasture, values with the same letter were not significantly different at $P<0.05$.

\begin{tabular}{|c|c|c|c|}
\hline & pasture $22 \mathrm{~W}$ & pasture $5 \mathrm{~W}$ & pasture $29-30$ \\
\hline Period I & swale $^{\mathrm{a}}>$ upland $^{\mathrm{b}}>$ rocky $^{\mathrm{b}}>$ town $^{\mathrm{b}}$ & swale $^{\mathrm{a}}>$ Atriplex $^{\mathrm{ab}}>$ town $^{\mathrm{bc}}>\mathrm{cw}^{\mathrm{c}}>$ rocky $^{\mathrm{c}}$ & 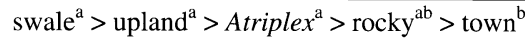 \\
\hline Period II & swale $^{\mathrm{a}}>$ upland $^{\mathrm{a}}>$ rocky $^{\mathrm{b}}>$ town $^{\mathrm{b}}$ & Atriplex $^{\mathrm{a}}>$ swale $^{\mathrm{ab}}>$ town $^{\mathrm{abc}}>\mathrm{cw}^{\mathrm{abc}}>$ rocky $^{\mathrm{c}}$ & town $^{\mathrm{a}}>$ Atriplex $^{\mathrm{a}}>$ upland $^{\mathrm{a}}>$ swale $^{\mathrm{a}}>$ rocky $^{\mathrm{b}}$ \\
\hline Combined & swale $^{\mathrm{a}}>$ upland $^{\mathrm{b}}>$ rocky $^{\mathrm{c}}>$ town $^{\mathrm{c}}$ & Atriplex $^{\mathrm{a}}>$ swale $^{\mathrm{a}}>$ town $^{\mathrm{b}}>\mathrm{cw}^{\mathrm{b}}>$ rocky $^{\mathrm{b}}$ & Atriplex $^{\mathrm{a}}>$ upland $^{\mathrm{a}}>$ swale $^{\mathrm{ab}}>$ town $^{\mathrm{b}}>$ rocky $^{\mathrm{c}}$ \\
\hline
\end{tabular}


Table 4. The proportion of behaviors of focal animals averaged over all 3 intensive survey pastures on the CPER, summer, 1999. Within a column, values with the same letter were not significantly different at $P<\mathbf{0 . 0 5}$. The designation "other" refers to behavior such as standing still, drinking water, or interacting with other cattle The designation "cw" refers to the crested wheatgrass habitat, "rocky" refers to rocky ridgetops, and "town" refers to prairie dog town.

\begin{tabular}{lccccr}
\hline \hline Habitat & grazing & resting & traveling & other & $\mathrm{n}$ \\
\hline rocky & $0.82^{\mathrm{a}}$ & $0.00^{\mathrm{a}}$ & $0.14^{\mathrm{a}}$ & 0.04 & 44 \\
Atriplex & $0.75^{\mathrm{a}}$ & $0.04^{\mathrm{a}}$ & $0.14^{\mathrm{a}}$ & 0.07 & 512 \\
upland & $0.62^{\mathrm{b}}$ & $0.14^{\mathrm{b}}$ & $0.11^{\mathrm{a}}$ & 0.13 & 614 \\
town & $0.60^{\mathrm{b}}$ & $0.13^{\mathrm{b}}$ & $0.15^{\mathrm{a}}$ & 0.12 & 108 \\
cw & $0.56^{\mathrm{bc}}$ & $0.30^{\mathrm{c}}$ & $0.07^{\mathrm{b}}$ & 0.07 & 27 \\
swale & $0.42^{\mathrm{c}}$ & $0.20^{\mathrm{bc}}$ & $0.07^{\mathrm{b}}$ & 0.31 & 415 \\
\hline
\end{tabular}

that in other habitats with the exception of the crested wheatgrass habitat and rocky ridgetops which had higher percentages of bare ground (Fig. 3).

Averaged over all 3 pastures and over July and August (Fig. 4), vegetation on prairie dog towns $($ mean $=6.4 \mathrm{~cm}$ ) was significantly shorter than that in all other habitats $($ mean $=11.9 \mathrm{~cm})$.

\section{Discussion}

Although Chi-square analysis of the 1999 driving survey data indicated that cattle significantly selected for prairie dog towns on this Colorado shortgrass steppe site, the magnitude of the effect was quite small $\left(B_{i}=0.527\right)$ and differed little from random use $\left(B_{i}=0.500\right)$. Clearly, cattle did not exhibit a strong preference for prairie dog towns as did bison on the mixed-grass prairie (Coppock et al. 1983b, Krueger 1986). However, $91 \%$ of the cattle observed on prairie dog towns during driving surveys were grazing. This may seem intuitive since we surveyed during peak grazing times; however this shows that cattle did not spend their time simply traveling across prairie dog towns to get to more preferred grazing areas. Instead, they actually spent a significant amount of time on the prairie dog towns actively using them as a foraging resource.

On the more intensively surveyed pastures, focal animals apparently represented herd movements well as more than half the herd was within $50 \mathrm{~m}$ of them. Preference rankings derived from log-ratio compositional analysis indicated that over the season, swales and Atriplex terrace habitats were usually most preferred and rocky ridgetops were often least preferred. In general, prairie dog towns were ranked near the middle or below, but significance tests did not indicate differences between the prairie dog towns and anywhere from 1 to 4 other habitats. Swales were highly ranked in all 3 pastures indicating that cat- gest that caution is required for gregarious animals. For this study, the focal animals appear to represent the movements of the herd and therefore we cautiously extrapolate our findings to the rest of the herd.

Bison on mixed-grass prairie were found to have significantly higher bite/step ratios on prairie dog towns compared to uncolonized areas in 5 of 6 months of the May to November study, excluding November (Krueger 1986). This implied greater forage quality on those prairie dog towns compared to the uncolonized area. In our study, the number of bites/step on prairie dog towns was not significantly different than productive habitats such as swales and Atriplex terraces. The foraging rate (bites/minute) for cattle on prairie dog towns was also not significantly different from swales, a preferred habitat. While bite size was not measured (and could have been smaller on prairie dog towns), this nevertheless implies that the plants on prairie dog towns have forage value. A study of cattle on the shortgrass steppe found that foraging velocities (rates of walking in steps/minute) only changed if the differences in forage quantity were
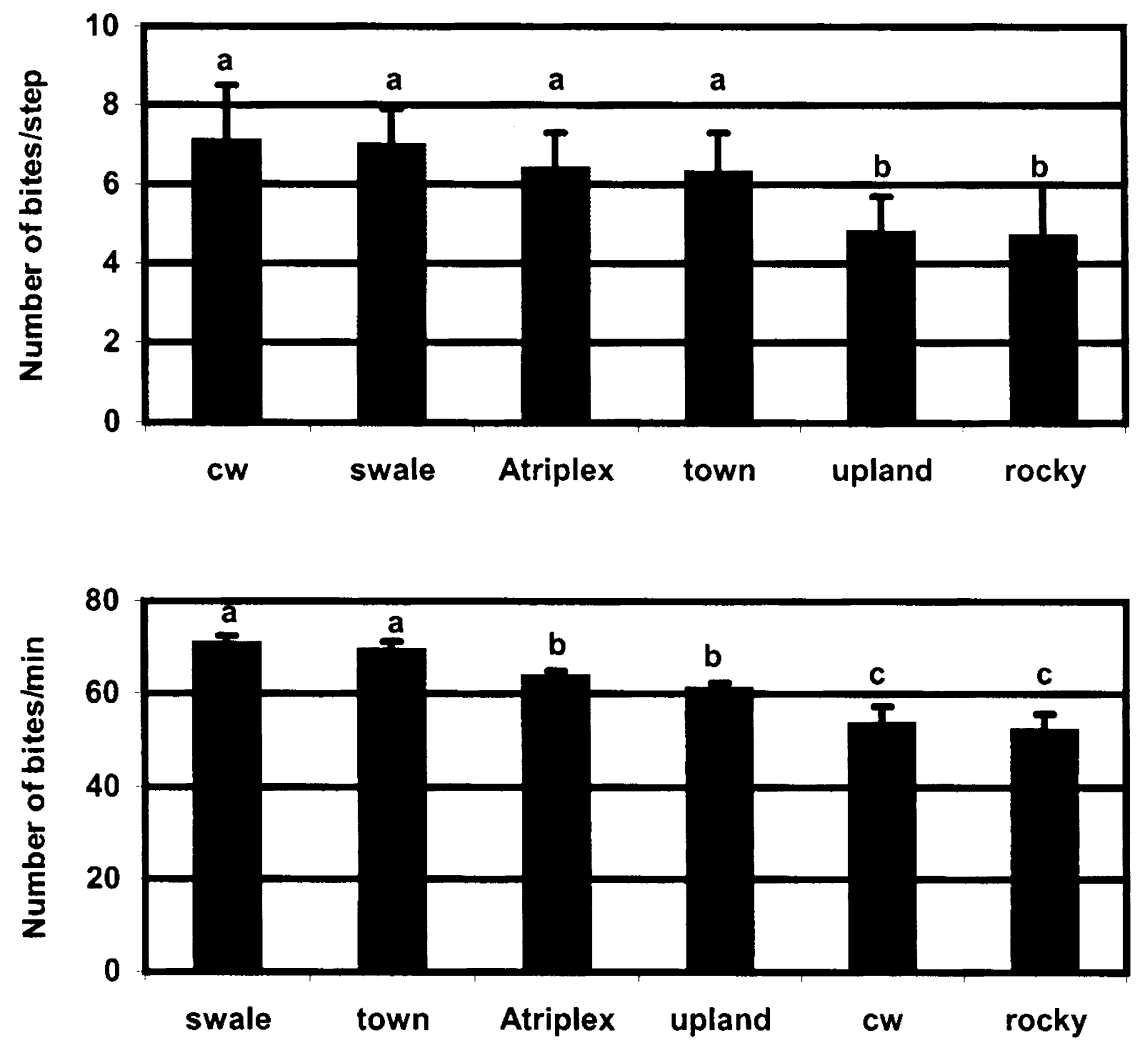

Fig. 2. Least squares means and standard errors of number of bites per step and bites per minute of foraging cattle by habitat ("cw" refers to the crested wheatgrass habitat, "rocky" refers to rocky ridgetops, and "town" refers to prairie dog towns). Sample sizes: swale $n=$ 118, prairie dog town $n=91$, Atriplex terrace $n=211, \mathrm{cw} n=20$, rocky ridgetop $n=24$, upland $\mathbf{n}=\mathbf{2 0 0}$. 

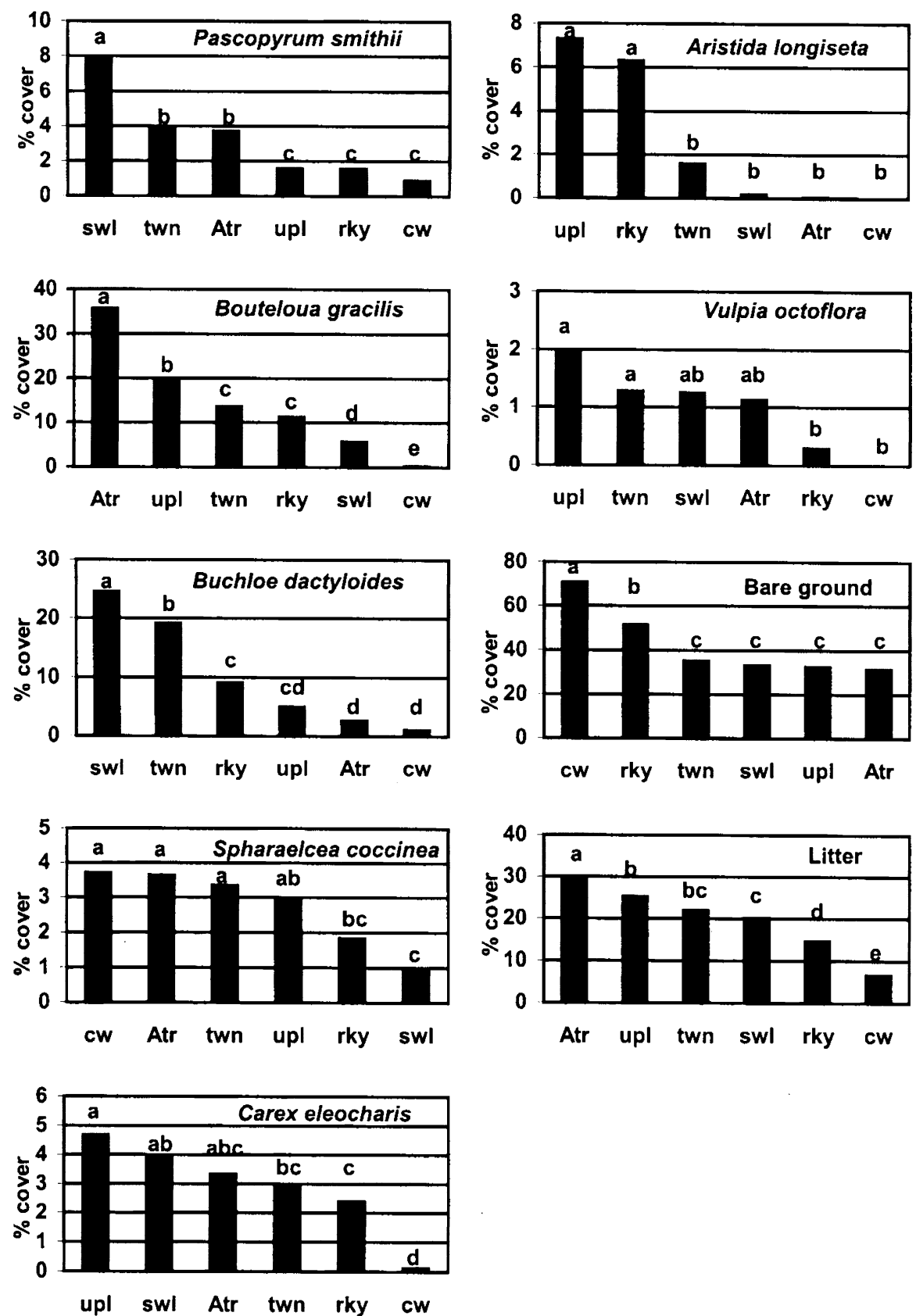

Fig. 3. Average cover (\%) for 5 plant species palatable to cattle (left column), 2 non-palatable species (Aristida longiseta and Vulpia octoflora), and for bare ground and litter on each habitat type. Cover is averaged over June, July, and August of 1999, and across the 3 intensively surveyed pastures on the CPER ("cw" refers to the crested wheatgrass habitat, "rky" refers to rocky ridgetops, "Atr" refers to Atriplex terraces, "upl" refers to upland habitat, "swl" refers to swales, and "twn" refers to prairie dog towns). Columns with the same letters were not significantly different at $\mathbf{P}<0.05$.

great (Bailey 1988, Bailey et al. 1996). It may be that the differences in forage quantity or quality between prairie dog towns and swales on the shortgrass steppe were not sufficiently large for cattle to change their foraging rates.

Our vegetation characterization indicates that plant species palatable to cattle such as western wheatgrass, blue grama, and scarlet globemallow (Vavra et al. 1977), are quite common on these shortgrass steppe prairie dog towns (Fig. 3). Non-palatable plants often had similar or higher cover off of prairie dog towns. The estimate for bare ground cover on prairie dog towns $(35.3 \%)$ in this study is essen- tially identical to what Archer et. al (1987) found on the mixed grass prairie of South Dakota (35\%). However, Archer et. al (1987) found more than 3 times as much bare ground on prairie dog towns as off, whereas on the shortgrass steppe, we found there to be as much or more bare ground on the other habitats as on prairie dog towns. One important difference found in vegetation on and off prairie dog towns was that the plants growing on prairie dog towns were significantly shorter than those on all of the other habitats. While cattle did not appear to be selecting prairie dog towns to graze on, they also did not significantly avoid them, even though the vegetation was shorter there.

It is not clear why we did not see a preference for prairie dog towns by cattle on the shortgrass steppe. Age of the prairie dog towns may be a factor. The towns used for this study were all relatively young (mean $=5$ years); however, areas of prairie dog towns selected for grazing by bison in mixed-grass prairie were of this age (Coppock et al. 1983b). Slope and the location of water tanks were not considered in the analysis of this study; however, the pastures were relatively flat with rolling hills (0-15\% slope) and care was taken to select prairie dog towns that did not have water tanks on or adjacent to them. Variability can also occur in the behavior of cows with calves versus steers. However, a combination of pastures with different cattle types was used for this study to obtain an overview of cattle behavior in general.

Year to year weather differences might have an effect on cattle selection of prairie dog towns on the shortgrass steppe. The summer of this study was unusually wet. The total precipitation for 1999 was $550 \mathrm{~mm}$, at the upper end of the range of precipitation for the shortgrass steppe. Green (1998) reported that during a wet year on the mixed-grass prairie, bison grazed on prairie dog towns preferentially. He attributed this to the additional moisture causing grasses on surrounding ungrazed habitat to grow taller and seed out, whereas the grazed grasses on prairie dog towns were not seeding out and had high leaf:stem ratios. During a dry year bison did not graze preferentially on the towns. On the shortgrass steppe, Lerwick (1974) found that prairie dogs and cattle switched diets during drought years with prairie dogs consuming more grass and cattle consuming more forbs than in nondrought periods. Variation in weather definitely has an effect on plant-herbivore and herbivore-herbivore relationships, and sur- 


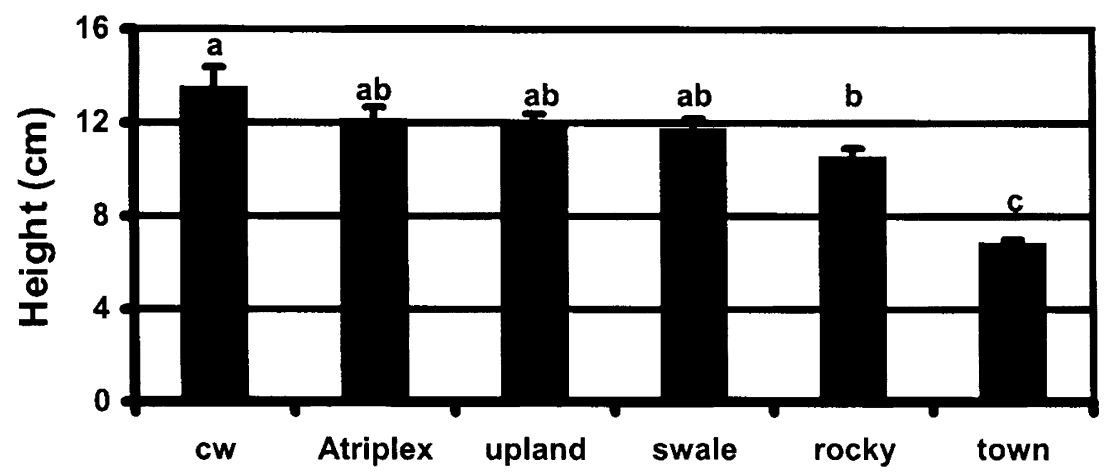

Fig. 4. Mean average height $(\mathrm{cm})$ and standard errors of vegetation for all habitats averaged over July and August, 1999 ("cw" represents the crested wheatgrass habitat, "rocky" refers to rocky ridgetops, and "town" refers to prairie dog towns).

veys conducted on the shortgrass steppe during a drought year might show very different results. However, since 1999 was a wet year, which would be similar to a normal weather year on the mixed-grass prairie, we would expect to see cattle preference for prairie dog towns during the summer of our study if we were to see it at all.

Nitrogen content of plants on and off prairie dog towns was not measured for this study. However, if there was indeed an increase in protein content in the plants on prairie dog towns as shown in the mixed-grass prairie (Coppock et al. 1983a), perhaps this increase on the shortgrass steppe (a place with less moisture) is not great enough to cause a preference but high enough to compensate for the loss in biomass. Therefore the habitat is used as expected and not avoided.

Coppock et al. (1983b) hypothesized that a response by large ungulates to prairie dog towns would likely only be seen in highly productive systems where the difference in habitat on and off towns is greatest. The shortgrass steppe is a very different system from the mixed grass prairie (Milchunas et al. 1998). Atsedu (1995) found differences in nitrogen content increases of grazed plants on the shortgrass steppe to be dependent on grazing histories and intensities. Also, cattle and bison are similar in that both are generalist herbivores, but cattle are more selective feeders (Peden et al. 1974). The examination of cattle use of prairie dog towns on mixed-grass prairie and of bison use of prairie dog towns on shortgrass prairie would provide insights as to whether it is cattle or the shortgrass system that is driving the preferences for prairie dog towns. Furthermore, the issue of carrying capacity is important (Hobbs and Hanley 1990). For example, how large or old does a prairie dog town have to be before it begins to affect the number of cattle that can be sustained on a pasture in the shortgrass steppe? More information is also needed on the effects of prairie dog grazing on the quantity and quality of forage for cattle on the shortgrass steppe.

\section{Literature Cited}

Aebischer, N. J., P. A. Robertson, and R. E. Kenward. 1993. Compositional analysis of habitat use from animal radio-tracking data. Ecol. 74:1313-1325.

Altmann, J. 1974. Observational study of behavior sampling methods. Behav. 49:227-267.

Archer, S., M. G. Garrett, and J. K. Detling. 1987. Rates of vegetation change associated with prairie dog (Cynomys ludovicianus) grazing in North American mixed-grass prairie. Vegetatio 72:159-166.

Arnold, G. W. and M. L. Dudzinski. 1978. Ethology of free-ranging domestic animals.Elsevier Scientific Publishing Co., Amsterdam, The Netherlands.

Atsedu, M. 1995. Defoliation responses of shortgrass steppe plants in relation to longand short-term grazing history. Ph.D. Diss. Colorado State Univ., Fort Collins, Colo.

Bailey, D. W. 1988. Characteristics of spatial memory and foraging behavior in cattle. Ph.D. Diss., Colorado State Univ., Ft. Collins, Colo.

Bailey, D. W., J. E. Gross, E. A. Laca, L. R. Rittenhouse, M. B. Coughenour, D. M. Swift, and P.L. Sims. 1996. Mechanisms that result in large herbivore grazing distribution patterns. J. Range Manage. 49:386-400.

Bonham, C. D. and A. Lerwick. 1976. Vegetation changes induced by prairie dogs on the shortgrass prairie. J. Range Manage. 29:221-225.

Coppock, D. L., J. K. Detling, J. E. Ellis, and M. I. Dyer. 1983a. Plant-herbivore interactions in a North American mixed-grass prairie I. Effects of black-tailed prairie dogs on intraseasonal aboveground plant biomass and nutrient dynamics and plant species diversity. Oecologia 56:1-9.
Coppock, D. L., J. E. Ellis, J. K. Detling, and M. I. Dyer. 1983b. Plant-herbivore interactions in a North American mixed-grass prairie II. Responses of bison to modification of vegetation by prairie dogs. Oecologia $56: 10-15$

Daubenmire, R. 1959. A canopy-coverage method of vegetational analysis. Northwest Sci. 33: 218-223.

Day, T. A. and J. K. Detling. 1994. Water relations of Agropyron smithii and Bouteloua gracilis and community evapotranspiration following long-term grazing by prairie dogs. Amer. Midl. Nat. 132:381-392.

Fahnestock, J. T. and J. K. Detling. 2002. Bison-prairie dog-plant interactions in a North American mixed-grass prairie. Oecologia 132:86-95.

Green, R. A. 1998. Nitrogen distribution in a perennial grassland: the role of American bison. Ph.D. Diss., Colorado State Univ., Ft. Collins, Colo.

Hansen, R. M. and I. K. Gold. 1977. Blacktail prairie dogs, desert cottontails, and cattle trophic relations on shortgrass range. J. Range Manage. 30:210-214.

Hazlett, D. L. 1998. Vascular plant species of the Pawnee National Grassland. General Tech. Rep. RMRS-GTR-17. Fort Collins, Colo: U.S. Dept. of Agr, Forest Serv., Rocky Mountain Res. Sta. $26 \mathrm{pp}$.

Hobbs, N. T. and T. A. Hanley. 1990. Habitat evaluation: do use/availability data reflect carrying capacity? J. Wildl. Manage. 54: 515-522

Krueger, K. 1986. Feeding relationships among bison, pronghorn, and prairie dogs: an experimental analysis. Ecol. 63:760-770.

Lauenroth, W. K. and D. G. Milchunas. 1991. Short-grass steppe, p. 183-226. In R. T. Coupland (ed.) Ecosystems of the world. Elsevier, New York, N.Y.

Lehner, P. N. 1996. Handbook of ethological methods. Second edition. Cambridge Univ. Press. Cambridge, Great Britain.

Lerwick, A. 1974. Effects of the black-tailed prairie dog on vegetation composition and their diet in relation to cattle. M.S. Thesis, Colorado State Univ., Ft. Collins, Colo.

Manly, B., L. McDonald, and D. Thomas. 1993. Resource selection by animals. Chapman and Hall. London, Great Britain.

Milchunas, D. G., W. K. Lauenroth, and I. C. Burke. 1998. Livestock grazing: animal and plant biodiversity of shortgrass steppe and the relationship to ecosystem function. Oikos 83:65-67.

O'Meilia, M. E., F. L. Knopf, and J. C. Lewis. 1982. Some consequences of competition between prairie dogs and beef cattle. J. Range Manage. 35:580-585.

Painter, E. L., J. K. Detling, and D. A. Steingraeber. 1993. Plant morphology and grazing history: relationships between native grasses and herbivores. Vegetatio 106:37-62.

Peden, D. G., G. M. Van Dyne, R. W. Rice, and R. M. Hansen. 1974. The trophic ecology of Bison bison L. on shortgrass plains. J. Appl. Ecol. 11: 489-198. 
Senft, R. L. 1983. The redistribution of nitrogen by cattle. Ph.D. Diss., Colorado State Univ., Ft. Collins, Colo.

Swift, D. M. 1983. A simulation model of energy and nitrogen balance for free-ranging ruminants. J. Wildl. Manage. 47:620-645.

Uresk, D. W. 1983. Prairie dogs as ecosystem regulators on the northern high plains, $\mathrm{p}$. 91-94. In: Seventh North American prairie conference, Proc. Aug 4-6, 1980.Southwest Missouri State Univ., Springfield, Mo.
Uresk, D. W. 1984. Black-tailed prairie dog food habits and forage relationships in western South Dakota. J. Range Manage. 37:325-329.

Uresk, D.W. 1985. Effects of controlling black-tailed prairie dogs on plant production. J. Range Manage. 38:466-468.

Vanderhye, A. V. R. 1985. Interspecific nutritional facilitation: Do bison benefit from feeding on prairie dog towns? M.S. Thesis, Colorado State Univ., Fort Collins, Colo.
Vavra, M., R. W. Rice, R. M. Hansen, and P. L. Sims. 1977. Food habits of cattle on shortgrass range in northeastern Colorado. $\mathrm{J}$. Range Manage. 30: 261-263.

Whicker, A. D. and J. K. Detling. 1988. Modification of vegetation structure and ecosystem processes by North American grassland mammals, p. 301-316. In: Werger, M. J. A., P. J. M. van der Aart, H. J. During and J. T. A. Verhoeven (eds.), Plant form and vegetation structure. SPB Academic Publishing, The Hague, The Netherlands. 